\title{
PENGARUH LATIHAN FISIK AEROBIK TERHADAP VO2 MAX PADA MAHASISWA PRIA DENGAN BERAT BADAN LEBIH (OVERWEIGHT)
}

\author{
${ }^{1}$ Intan Watulingas \\ ${ }^{2}$ Jornan J. V. Rampengan \\ ${ }^{2}$ Hedison Polii
}

\author{
${ }^{1}$ Kandidat Skripsi Fakultas Kedokteran Universitas Sam Ratulangi Manado \\ ${ }^{2}$ Bagian Fisiologi Fakultas Kedokteran Universitas Sam Ratulangi Manado \\ Email: intan_mui@rocketmail.com
}

\begin{abstract}
WHO predicts that by 2015, 2.3 billion adults will experience overweight. In Indonesia, the prevalence of the adult population who are overweight and obesity amounted to $21.7 \%$. Aerobic exercise is one of the solution to help overweight person, it also to assess a person's fitness in aerobic physical exercise is to measure maximal oxygen consumption $\left(\mathrm{VO}_{2} \max \right) . \mathrm{VO}_{2}$ max is the maximum amount of oxygen that can be consumed during physical activity until exhaustion occurred. The aim of this study was to prove the benefits of aerobic physical exercise on $\mathrm{VO}_{2}$ max in older men with overweight. The subjects consisted of 28 adult men with overweight. $\mathrm{VO}_{2}$ max values were measured before and after treatment using the astrand treadmill test. To see the effect of aerobic physical exercise program on $\mathrm{VO}_{2}$ max value analysis using a paired ttest to compare the change in the value of $\mathrm{VO}_{2}$ max before and after physical exercise. There is a higher $\mathrm{VO}_{2}$ max values in students with overweight men who got aerobic exercise for 3 weeks.
\end{abstract}

Key Word: overweight, aerobic exercise, $\mathrm{VO}_{2} \max$.

\begin{abstract}
Abstrak: badan lebih merupakan akumulasi lemak abnormal atau berlebihan yang dapat mengganggu kesehatan. WHO memprediksikan bahwa pada tahun 2015, 2,3 milyar orang dewasa akan mengalami berat badan lebih. Di Indonesia prevalensi penduduk dewasa yang mengalami berat badan lebih dan obesitas sebesar $21.7 \%$. Salah satu cara untuk mengurangi masalah berat badan lebih dengan melakukan latihan fisik aerobic dan untuk menilai kebugaran seseorang dalam melakukan latihan fisik aerobik antara lain dengan mengukur konsumsi oksigen maksimal $\left(\mathrm{VO}_{2}\right.$ max). $\mathrm{VO}_{2}$ max adalah jumlah maksimal oksigen yang dapat dikonsumsi selama aktivitas fisik.Tujuan dari penelitian ini adalah untuk membuktikan manfaat pengaruh latihan fisik aerobik terhadap $\mathrm{VO}_{2}$ max pada pria dewasa dengan berat badan lebih. Subyek terdiri dari 28 orang pria dewasa dengan berat badan lebih. Nilai $\mathrm{VO}_{2}$ max diukur sebelum dan sesudah perlakuan dengan menggunakan metode astrand treadmill test. Untuk melihat adanya pengaruh program latihan fisik aerobik terhadap nilai $\mathrm{VO}_{2}$ max dilakukan analisis dengan menggunakan uji-t berpasangan untuk membandingkan perubahan nilai $\mathrm{VO}_{2}$ max sebelum dan sesudah latihan fisik. Terdapat peningkatan nilai $\mathrm{VO}_{2}$ max pada mahasiswa pria dengan berat badan lebih yang mendapat latihan fisik aerobik selama 3 minggu.
\end{abstract}

Kata kunci: berat badan lebih, latihan fisik aerobik, $\mathrm{VO}_{2}$ max.

Berat badan lebih terjadi bila besar dan jumlah sel lemak bertamba pada tubuh seseorang maka ukuran sel lemak akan bertamba besar dan kemudian jumlahnya bertambah banyak ${ }^{1}$. Berat badan lebih merupakan akumulasi lemak yang abnormal atau berlebihan yang berpeluang menimbulkan efek buruk pada kesehatan. Ukuran 
untuk berat badan lebih indeks massa tubuh (IMT) $23-24.9 \mathrm{~kg} / \mathrm{m}^{2}$, dan obesitas IMT 25$30 \mathrm{~kg} / \mathrm{m}^{2}$ sudah menjadi suatu epidemiologi dinegara maju. Saat ini diperkirakan jumlah orang di seluruh dunia dengan IMT 30 $\mathrm{kg} / \mathrm{m}^{2}$ melebihi 250 juta orang, yaitu sekitar $7 \%$ dari populasi orang dewasa di dunia. ${ }^{2}$ Berat badan lebih merupakan salah satu masalah kesehatan masyarakat di Amerika Serikat dan semua negara industri dunia. Sebagai contoh di Amerika dua pertiga dari jumlah penduduknya mengalami hal ini. ${ }^{3}$ Prevalensi berat badan lebih di Indonesia sendiri juga masih tinggi. Menurut data Riset Kesehatan Dasar (Riskesdas) pada tahun 2010, di Indonesia prevalensi penduduk dewasa yang mengalami berat badan lebih dan obesitas sebesar $21.7 \%$ dan prevalensi tertinggi untuk berat badan lebih dan obesitas berada di Provinsi Sulawesi Utara (37,1\%), dan yang terendah adalah 13,0 persen di provinsi Nusa Tenggara Timur. $^{4}$

Salah satu cara untuk mengurangi masalah berat badan lebih dengan melakukan latihan fisik aerobik. Latihan fisik aerobik sangat baik untuk menurunkan berat badan karena menggunakan kalori lebih besar dan membantu meningkatkan metabolisme, dan membantu tubuh membakar kalori yang lebih cepat. Latihan fisik aerobik dapat menjadi cara yang efektif untuk menurunkan lemak dan dilakukan secara rutin. Latihan fisik aerobik yang diterapkan adalah dengan menggunakan sepeda statis. Menggunakan speda statisbagi orang yang memiliki kelebihan berat badan berguna untuk kebugaran jantung (kardiovaskuler), membangun ketahanan dan kekuatan otot terutama pada paha dan kaki.

Salah satu cara untuk menilai kebugaran seseorang dalam melakukan aktifitas fisik adalah dengan mengukur $\mathrm{VO}_{2}$ max. $\mathrm{VO}_{2}$ max adalah jumlah maksimum oksigen dalam milliliter, yang dapat digunakan dalam satu menit per kilogram berat badan. Orang yang kebugarannya baik mempunyai nilai $\mathrm{VO}_{2}$ max yang lebih tinggi dan dapat melakukan aktifitas lebih kuat dari pada mereka yang tidak dalam kondisi baik. ${ }^{5}$
Konsumsi oksigen maksimal $\left(\mathrm{VO}_{2}\right.$ max) adalah jumlah maksimal oksigen yang dapat dikonsumsi selama aktivitas fisik yang intens sampai akhirnya terjadi kelelahan. Nilai $\mathrm{Vo}_{2}$ max bergantung pada keadaan kardiovaskular, respirasi, hematologi, dan kemampuan latihan. Pengukuran nilai $\mathrm{VO}_{2}$ max ini dapat digunakan untuk menganalisis efek dari suatu program latihan fisik.Orang yang kebugarannya baik mempunyai nilai $\mathrm{VO}_{2}$ max yang lebih tinggi dan dapat melakukan aktifitas lebih kuat daripada mereka yang tidak dalam kondisi baik. ${ }^{6}$

Berat badan lebih dapat dikatakan memiliki lemak tubuh yang banyak dan kebugaran jasmani yang rendah dan mempunyai nilai $\mathrm{VO}_{2}$ max yang rendah. Untuk meningkatkan $\mathrm{VO}_{2}$ max perlu melakukan latihan fisik. Penulis tertarik untuk meneliti pengaruh latihan fisik dengan speda statis terhadap nilai $\mathrm{VO}_{2}$ max pada mahasiswa pria dengan berat badan lebih.

\section{Rumusan masalah}

Apakah latihan fisik aerobik dapat meningkatkan nilai $\mathrm{VO}_{2}$ max pada mahasiswa pria dengan berat badan lebih?

\section{Tujuan penelitian}

Untuk mengetahui pengaruh latihan fisik aerobikterhadap nilai $\mathrm{VO}_{2} \max$ pada mahasiswa pria dengan berat badan lebih (overweight)

\section{METODOLOGI PENELITIAN}

\section{Waktu dan lokasi penelitian}

Penelitian dilakukan selama bulan Desember, lokasi pre-test,perlakuan, dan post-test bertempat di salah satu pusat kebugaran tubuh (fitness cetre) di kota Manado.

\section{Subyek penelitian}

Populasi penelitian adalah mahasiswa Fakultas Kedokteran UNSRAT Program Studi Kedokteran Umum angkatan 2009 berjumlah 350 orang. Subyek penelitian berjumlah 32 mahasiswa yang memenuhi kriteria inklusi yaitu laki-laki berusia 18-25 
1066 Jurnal e-Biomedik (eBM), Volume 1, Nomor 2, Juli 2013, hlm. 1064-1068

tahun dengan IMT $\geq 23 \mathrm{~kg} / \mathrm{m}^{2}$ dan layak mengikuti program latihan (seleksi dengan kuisioner $P A R-Q$ ), jumlah subyek yang menyelesaikan penelitian hanya 28 mahasiswa.

\section{Pengumpulan Data}

\section{Pre-test}

Pada pre-test dilakukan dengan menggunakan treadmill pada subyek penelitian sebelum melakukan program latihan. Nilai yang digunakan adalah ketika penguji menghentikan stopwatchdan mencatat waktu ketika subyek tidak dapat melanjutkan.

\section{Treatment/perlakuan}

Pada tahap ini diberikan latihan menggunakan sepeda statis dengan program sebagai berikut;

Tabel1. Program latihan fisik aerobik

\begin{tabular}{lll}
\hline Waktu & Aktivitas & Heart Rate \\
\hline 0:00 -5:00 & Pemanasan & -- \\
5:01-25:00 & Latihan Inti & 70\%-80\%HRmax \\
25:01-30:00 & Pendinginan & -- \\
\hline
\end{tabular}

Latihan dilakukan selama 3 minggu dengan frekwensi latihan tiga kali dalam satu minggu.

\section{Post-test}

Proses post-test menggunakan treadmillsama dengan proses pengukuran pada pre-test, pengukuran dilakukan hari terakhir pada minggu ketiga yang dilakukan oleh subyek.

\section{Analisis Data}

Hasil penelitian didapat dari penghitungan data yang diperoleh dengan menggunakan analisis dengan perangkat lunak SPSS versi 20 menggunakan uji-t untuk melihat adanya pengaruh program latihan aerobik terhadap nilai $\mathrm{Vo}_{2}$ max.

\section{HASIL PENELITIAN}

\section{Karakteristik subyek}

Subyek yang selesai mengikuti penelitian sebanyak 28 orang yang merupakan mahasiswa Fakultas Kedokteran Unsrat angkatan 2009, berusia 19-22 tahun, berbadan sehat dan layak mengikuti program latihan fisik, tidak minum alkohol dan obat lainnya yang dapat mempengaruhi fungsi paru. Karakteristik subyek diringkas seperti pada Tabel 2

Tabel 2. Karakteristik fisik subyek

\begin{tabular}{lll}
\hline & \multicolumn{1}{c}{$\begin{array}{c}\text { Nilai } \\
\text { Kisaran }\end{array}$} & Rerata \\
\hline Umur (Tahun) & $19-22$ & 20.85 \\
Tinggi Badan $(\mathrm{Cm})$ & $163-183$ & 171.28 \\
Berat Badan (Kg) & $65-112$ & 77.78 \\
$\begin{array}{l}\text { Indeks Massa Tubuh } \\
\left(\mathrm{Kg} / \mathrm{m}^{2}\right)\end{array}$ & $23.29-39.21$ & 26.50 \\
\hline
\end{tabular}

Data menyatakan bahwa subyek mempunyai ciri-ciri keadaan fisik dengan kelebihan berat badan (overweight) dilihat dari kisaran dan rerata IMT.

Nilai $\mathrm{Vo}_{2}$ maxsebelum dan sesudah program latihan aerobik.

Tabel 3 menunjukan data nilai volume oksigen maximal ( $\mathrm{VO}_{2}$ max)subyeksebelum dan sesudah mengikuti program latihan aerobik.

Tabel 3. Rerata nilai $V_{2} M A X$ sebelum latihan dan sesudah latihan

\begin{tabular}{lll}
\hline & $\boldsymbol{V O}_{2} \boldsymbol{M A X}$ & \\
\cline { 2 - 3 } & Kisaran & Rerata \\
\hline Sebelum & $22.93-$ & 30.05 \\
(ml/kg/menit) & 39.54 & \\
Sesudah & $27.00-$ & 35.73 \\
(ml/kg/menit) & 51.09 & \\
\hline
\end{tabular}

Berdasarkan hasil Tabel 3 menunjukan perbandingan nilai rerata $\mathrm{VO}_{2}$ Max sebelum 
perlakuan (30.05 ml/kg/menit) dan sesudah perlakuan (35.73 ml/kg/menit).

\section{VO2 Max (ml/kg/menit)}

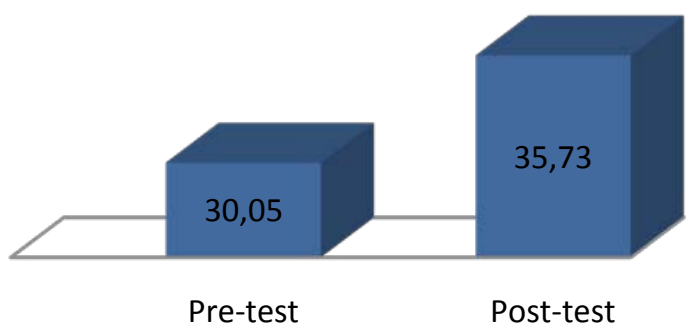

Gambar 1. Histogram Rerata Nilai $\mathrm{VO}_{2}$ maxSebelum dan Sesudah Perlakuan

\section{BAHASAN}

\section{Karakteristik subyek}

Hasil analisis statistik dengan menggunakan uji t berpasangan didapatkan bahwa nilai $\mathrm{VO}_{2}$ Max didapatkan hasil secara bermakna $\mathrm{p}=0,000$. Hal ini terdapat pada hasil rerata nilai $\mathrm{VO}_{2}$ max sebelum perlakuan sebesar $30.05 \mathrm{ml} / \mathrm{kg} /$ menit dan sesudah perlakuan sebesar 35.73 $\mathrm{ml} / \mathrm{kg} / \mathrm{menit}$. Dari hasil analisis data penelitian didapat bahwa terjadi peningkatan nilai $\mathrm{VO}_{2}$ Max sesudah perlakuan pada Mahasiswa Fakultas Kedokteran Universitas Samratulangi Manado Angkatan 2009.

\section{Pengaruh latihan aerobik terhadap $\mathrm{VO}_{2}$ max}

Peningkatan nilai $\mathrm{VO}_{2}$ Max pada mahasiswa yang melakukan latihan fisik aerobic dengan menggunakan sepeda statis, peningkatan ini dipengaruhi oleh beberapa hal yaitu: latihan Fisik, fungsi kardiovaskular, komposisi tubuh dan penurunan denyut jantung.

Latihan fisik adalah proses memperkembangkan kemampuan aktivitas gerak jasmani yang dilakukan secara sistematik dan ditingkatkan secara progresif untuk mempertahankan atau meningkatkan derajat kebugaran jasmani agar tercapai kemampuan kerja fisik yang optimal. Unsur-unsur penting yang terkandung dalam latihan fisik meliputi kekuatan, daya tahan, kelenturan, keseimbangan, kecepatan, kelincahan, stamina, koordinasi.Respon kardiovaskuler yang paling utama terhadap aktivitas fisik adalah peningkatan cardiac output. Peningkatan ini disebabkan oleh peningkatan isi sekuncup jantung maupun heart rate yang dapat mencapai sekitar 95\% dari tingkat maksimalnya. Pemakaian oksigen oleh tubuh tidak dapat lebih dari kecepatan sistem kardiovaskuler menghantarkan oksigen ke jaringan, maka dapat dikatakan bahwa sistem kardiovaskuler dapat membatasi nilai $\mathrm{VO}_{2}$ Max.Komposisi tubuh, konsumsi oksigen maksimal $\left(\mathrm{VO}_{2} \mathrm{Max}\right)$ dinyatakan dalam beberapa milliliter oksigen yang dikonsumsi per $\mathrm{kg}$ berat badan, perbedaan komposisi tubuh seseorang menyebabkan konsumsi yang berbeda. Misalnya tubuh mereka yang mempunyai lemak dengan persentasi tinggi mempunyai konsumsi oksigen maksimum yang lebih rendah. Sebab itu, jika dapat mengurangi lemak dalam tubuh, konsumsi oksigen maksimal dapat bertambah tanpa tambahan latihan. Penurunan Denyut Jantung: Orang yang terlatih akan memiliki denyut jantung istirahat yang lebih rendah daripada orang yang tidak terlatih. Denyut jantung yang lebih rendah mengakibatkan nilai $\mathrm{VO}_{2}$ max pada orang terlatih menjadi lebih tinggi. Denyut jantung dapat mengalami penurunan setelah melakukan latihan fisik selama waktu tertentu, ini adalah kompensasi tubuh terhadap latihan fisik. Akibatnya orang yang terlatih akan bekerja lebih efektif daripada orang yang tidak terlatih. $^{7}$

Hasil penelitian yang dilakukan oleh Chatterjee P dkk di India (2008) dengan penelitian menggunakan uji-t berpasangan. Nilai $\mathrm{VO}_{2}$ max sebelum perlakuan 31.30 setelah perlakuan 50.30. Nilai $\mathrm{VO}_{2}$ Max mengalami peningkatan. ${ }^{8}$

Hasil penelitian yang dilakukan oleh Uliyandary A didapat hasil bahwa terjadi peningkatan nilai $\mathrm{VO}_{2}$ Max pada kelompok perlakuan, yaitu siswi Sekolah Bola Voli Tugu Muda Semarang usia 11-13 tahun setelah melakukan latihan fisik terprogram.

Latihan fisik aerobik dapat meningkatkan nilai $\mathrm{VO}_{2}$ Max. Akan tetapi peningkatan ini hanya terbatas sekitar 10$20 \%$, karena adanya keterbatasan waktu 
sehingga latihan fisik aerobik hanya dilakukan dalam 3 kali seminggu selama 3 minggu sehingga peningkatan tidak maksimal. Seharusnya waktu yang dianjur-kan adalah minimal 8 minggu dan maksimal 12 minggu untuk mendapatkan hasil yang maksimal pula.

Hasil penelitian yang telah dilakukan menunjukkan bahwa latihan fisik aerobik dapat meningkatkan nilai $\mathrm{VO}_{2}$ Max.

\section{SIMPULAN}

Dari penelitian ini didapatkan kesimpulan bahwa latihan fisik aerobic selama 3 minggu dapat meningkatkan nilai $\mathrm{VO}_{2}$ max secara bermakna.

\section{UCAPAN TERIMA KASIH}

Ucapan terima kasih disampaikan pada dr. D. C. H. Pangemanan M.Kes, AIFM, AIFO dan Dr. Herlina I. S. Wungouw, Ms.App.Sc, M.Med.Ed, AIFM, AIFO, dan pada semua pihak yang baik secara langsung maupun tidak langsung telah menumbuhkan ide/gagasan dalam pemikiran penulisan sehingga dapat menyelesaikan artikel ini.

\section{DAFTAR PUSTAKA}

1. Nurhalima R, Vallery B, Pencegahan dan Manajemen Obesitas. Penerbit PT Elex Media Komputindo, Kompas Gramedia, Jakarta, 2011
2. Sugondo S, Obesitas. Buku Ajar Ilmu Penyakit Dalam Jilid III. Edisi V. Jakarta. Interna Publishing. 2009. Hal: 1973-83

3. Galletta GM. 2012. Obesity. eMedicine Health, expert of everyday emergencies. Available at: http://www.emedicine health.com/obesity/article_em.htm (diakses tanggal 12 Januari 2012)

4. Badan Penelitian dan Pengembangan Kesehatan. Riset Kesehatan Dasar 2010. Kementerian Kesehatan RI. 2010. Tersedia dalam: http://www.litbang. depkes.go.id/sites/download/buku_laporan /lapnas_riskesdas2010/Laporan_riskesdas _2010.pdf

5. Maqsalmina M. Pengaruh latihan aerobic terhadap perubahan Vo2 max pada siswa sekolah sepak bola tugu muda semarang usia 12-14 tahun. Skripsi. Fakultas Kedokteran Universitas Diponegoro. Semarang. 2007

6. Uliyandari A. Pengaruh latihan fisik terprogram terhadap perubahan nilai konsumsi oksigen maksimal $\left(\mathrm{VO}_{2}\right.$ max) pada siswi sekolah bola voli tugu muda semarang usia 11-13 tahun. Skripsi. Semarang: Fakultas Kedokteran universitas Diponegoro, 2009

7. Faruk M. Survey tingkat kebugaran jasmani pada pemain persatuan sepakbola Indonesia lumajang agung septian nosa. Artikel. Fakultas ilmu keolahragaan

8. Chatterjee $\mathrm{P}$, Banerjee $\mathrm{A} \mathrm{K}$, Das $\mathrm{P}$, Debnath P and Chatterjee P. Regression Equations to Predict VO2 Max in Untrained Boys and Junior Sprinters of Kolkata. Journal of Exercise Science and Physiotherapy, Vol. 4, No. 2: 104-108, 2008. 